\title{
FAKTOR YANG MEMPENGARUHI PRESTASI BELAJAR PESERTA DIDIK DI KELAS X SMK NEGERI 3 PADANG
}

\author{
Fenni Agrianti, Mori Dianto, dan Citra Imelda Usman \\ Program Studi Bimbingan dan Konseling STKIP PGRI Sumatera Barat \\ agriantifenni@gmail.com
}

\begin{abstract}
This research is motivated by the presence of students who are less able to adapt to the situation or problem that is being faced, so that it has an impact on their learning achievement. The purpose of this study is to describe: 1) Internal factors that affect student achievement. 2) External factors that affect student achievement. This research uses descriptive quantitative method. The study population was 247 students selected by purposive sampling technique with 45 participants. Based on the research results obtained as follows: 1) Internal factors that affect student achievement are in the low category 2) External factors that affect student achievement are in the low category. The results of this study are recommended for guidance and counseling teachers to develop special programs related to improving student learning achievement so that students can achieve the desired achievement.
\end{abstract}

Keywords: Student Learning Achievement

\section{PENDAHULUAN}

Pendidikan anak yaitu sesuatu begitu sangat berarti yang tidak bisa dianggap spele oleh siapapun termasuk orang tua. Pendidikan adalah usaha dalam menumbuhkembangkan semua keterampilan serta sikap individu dengan proses belajar mengajar. Pendidikan pada arti luas yaitu melatih, membimbing, mengajar serta mendidik seseorang.

Pada semua prosedur pendidikan di sekolah, aktivitas belajar yaitu tindakan yang utama. Sekolah yaitu pokok lembaga pendidikan yang membimbing individu agar memahami bidang belajar secara formal. Kegiatan belajar berupa usaha yang dilaksanakan seseorang agar mendapat wawasan dan pengalam baru yang bisa dilihat dari perubahan sikap yang lebih baik. Perubahan sikap itu dikarenakan ada hubungan individu dan lingkungan belajarnya. Jadi, dengan kegiatan pembelajaran maka kemampuan peserta didik bisa 
dioptimalkan untuk mendapatkan sumber daya manusia yang berkualitas. Maksud serta tujuan diselenggarakannya kegiatan pembelajaran adalah memperbaiki keberhasilan hasil pembelajaran siswa.

Peserta didik yaitu individu yang mempunyai kemampuan dasar, yang sangat penting dikembangkan dengan pendidikan, baik itu fisik ataupun psikis, pendidikan itu ada yang di lingkungan keluarga, sekolah ataupun dimasyarakat tempat anak berinteraksi.

Ahmadi \& Supriyono, 2011 (Syafi'i et al., 2018:121) mengemukakan ada dua faktor yang dapat mempengaruhi prestasi dalam belajar, lebih jelasnya sebagai berikut:

1. FaktorInternal

a. Faktor jasmani dilihat pada indra penglihatan, dan strukturtubuh

b. Faktor psikologi, yaitu;

1. Faktor dalam;

a. Aspek intelektif merupakan kepintaran, kebijakan merupakan suatu hasil yang telah dicapai b. Aspek non intelektif melingkupi perbuatan, hobi, keinginan, dorongan, perasaan.

2. Faktor Eksternal ;

a. Faktor sosial ada;

1) Situasi keluarga

2) Situasi sekolah

3) Situasi masyarakat

4) Situasi kelompok

b. Faktor budaya contohnya peraturan adat, wawasan dasar, kesenian dan teknologi.

c. Faktor lingkungan fisik contohnya kelengkapan rumah, kelengkapan belajar, kondisi.

Prestasi yang didapatkan atau keberhasilan dalam pendidikan bisa dilihat dari keberhasilan tes potensi akademik (contohnya ulangan harian, ujian nasional). Bisa juga prestasi dibidang lainnya contohnya prestasi disuatu cabang keterampilan, seni, olahraga dan keterampilan lainnya. Ataupun prestasi sekolah yang berbentuk situasi yang hanya dirasakan contohnya situasi disiplin, keakraban seperti saling menghormati, menjaga kebersihan dan lain sebagainya. 
Sesuai paparan di atas peneliti menyimpulkan sangat perlu dalam mengetahui prestasi belajar peserta didik, baik secara individu maupun kelompok. Karena prestasi belajar sangat berpengaruh terhadap dunia pendidikan. Faktor yang mendorong prestasi belajar itu bisa di pengaruhi dari suasana sekitar (suasana keluarga, suasana sekolah dan suasana masyarakat). Pencapaian belajar bisa dikatakan prestasi belajar, belajar yang sungguhsunggug bisa memperoleh prestasi belajar yang baik, dan belajar dengan keterpaksaan bisa memperoleh prestasi yang buruk. Prestasi belajar yaitu sebuah penghargaan yang dibagikan oleh guru kepada peserta didik yang sudah berpartisipasi pada proses pembelajaran.

Menurut Putu dkk. (2014:2) dalam meningkatkan prestasi belajar bisa diberikan informasi yang berkenaan kualitas pendidikan seperti mengelola pembelajaran dan melakukan layanan bimbingan dan konseling kepada peserta didik. Oleh karena itu diusahakan supaya peserta didik bisa meraih prestasi belajar yang maksimal berdasarkan dengan tujuan kurikulum. Terfokuskan pada peserta didik yang berprestasi rendah di bawah rata-rata kelas, jadi sangat penting upaya dalam meningkatkan melalui layanan konseling.

Menurut

Kamaluddin (2011:448) bimbingan dan konseling yaitu sebuah usaha yang dilakukan dalam upaya memberikan hal yang bisa membuat individu berkembang dengan baik. Pendapat Hikmawati (2011:1) Bimbingan dan konseling yaitu suatu bentuk pemberian suatu hal kepada klien yang bertujuan untuk memandirikan klien agar bisa menyelesaikan sebuah masalah yang dihadapi.

(Bhakti, 2015:100) menjelaskan bahwa program bimbingan dan konseling dilaksanakan dengan rangkaian kegiatan yang terstruktur dari merencanakan desain, implementasi, evaluasi dan tindak lanjut. Dengan menetapkan fungsi-fungsi manajemen itu diminta proses layanan bimbingan dan konseling bisa dilakukan dengan terukur dan tepat sasaran.

Sesuai paparan di atas bahwa bimbingan konseling sangat penting 
diberikan oleh peserta didik, yang mana bimbingan konseling ini dapat mendorong seseorang dalam memahami stiap yang ada pada dirinya dan membantu peserta didik dalam mencari jalan keluar atas kendala yang sedang dihadapinya.

Sesuai yang didapatkan peneliti dari hasil observasi pada Tanggal 16 Oktober 2019 di SMK Negeri 3 Padang, adanya peserta didik yang mengalami gangguan penglihatan sehingga mendapatkan nilai yang rendah, adanya peserta didik yang sulit memahami diri sendiri dalam proses pembelajaran, adanya siswa yang mempunyai motivasi yang rendah, adanya peserta didik yang belum mencukupi syarat ketuntasan minimal (KKM), sehingga harus mengikuti ulangan perbaikan. Adanya peserta didik yang masih belum bisa menerima lingkungan sekitar dalam belajar kelompok, adanya peserta didik yang kurang mendapati perhatian dari orang tua dalam proses pembelajaran, sehingga mengakibatkan kurang bersemangatnya siswa dalam belajar, adanya siswa yang memiliki ekonomi menengah ke bawah sehingga membuatnya jadi sering bolos dan prestasi belajarnya menjadi rendah.

Berdasarkan hasil wawancara pada Tanggal 4 November dengan guru mata pelajaran dan peserta didik sebanyak 6 orang yang sudah peneliti lakukan, bahwa siswa banyak yang mendapat nilai rendah atau di bawah KKM, ada siswa yang sering bolos, ada juga peserta didik kurang mampu menyesuaikan diri dengan situasi atau masalah yang sedang dihadapi, sehingga berdampak pada prestasi belajarnya, ditemui beberapa permasalahan dalam pelaksanaan layanan bimbingan dan konseling, yaitu masalah waktu, layanan yang diberikan hanya bersifat insidental dan fungsinya terfokus pada pengentasan masalah. Dari permasalahan tersebut maka guru harus memberikan pelayanan bimbingan dan konseling kepada siswa supaya permasalahan yang terjadi bisa terselesaikan.

Berdasarkan hal tersebut pentingnya prestasi belajar bagi peserta didik sangat berpengaruh terhadap nilai peserta didik, karena 
itu peneliti tertarik untuk melaksanakan penelitian judul skripsi dengan judul "Penerapan Layanan Konseling Individual Berbasis Faktor Yang Mempengaruhi Prestasi Belajar Peserta Didik di Kelas X SMK Negeri 3 Padang”.

\section{METODE PENELITIAN}

Penelitian ini menggunakan metode kuantitatif dengan pendekatan deskriptif. Penelitian deskriptif menurut penelitian deskriptif kuantitatif. Iskandar (2009:17) mengemukakan bahwa "Penelitian kuantitatif merupakan yang dilaksanakan guna memperoleh hasil yang terlihat dari masalah yang timbul tentang suatu fenomena atau gejala yang dilandasi pada teori, asumsi atau andaian". Populasi penelitian adalah 247 siswa yang dipilih memakai teknik purposif sampling dengan 45 partisipan. Instrumen yang digunakan yaitu angket. Sedangkan untuk analisis data menggunakan klasifikasi persentase dan korelasi.

\section{HASIL DAN PEMBAHASAN}

Pada poin ini akan dijabarkan pembahasan berdasarkan analisis, penafsiran, temuan penelitian mengenai faktor yang mempengaruhi prestasi belajar peserta didik kelas $\mathrm{X}$ di SMK Negeri 3 Padang.
1. Faktor Internal yang Mempengaruhi Prestasi Belajar Peserta Didik

Berdasarkan hasil pengolahan data, bisa dipahami faktor internal yang mempengaruhi keberhasilan belajar siswa terdapat 1 orang siswa $(2,22 \%)$ yang memiliki faktor internal yang tinggi, sebanyak 10 orang peserta didik $(22,22 \%)$ yang memiliki faktor internal yang cukup tinggi, sebanyak 27 orang peserta didik $(60,00 \%)$ yang memiliki faktor internal yang rendah,sebanyak 7 orang peserta didik $(15,56 \%)$ yang memiliki faktor internal yang sangat rendah dan tidak terdapat siswa yang memiliki faktor internal dalam klasifikasi yang sangat tinggi. Jadi, faktor eksternal yang mempengaruhi prestasi belajar peserta didik di SMK Negeri 3 Kota Padang berada diklasifikasi rendah(55,56\%).Artinya sebagian besar peserta didik memiliki faktor internal yang rendah. 
Selanjutnya akan dibahas secara perindikator :

a. Faktor Internal yang Mempengaruhi Prestasi Belajar Peserta Didik Dilihat dari Faktor Jasmani Hasil penelitian menunjukan faktor dari dalam yang mempengaruhi prestasi belajar terfokus pada faktor jasmanidi SMK Negeri 3 Kota Padang berada pada kategori cukup tinggi $(44,44 \%)$. Artinya sebagian besar siswa mempunyai faktor jasmani yang rendah.

Berdasarkan hasil penelitian factor jasmani yang mempengaruhi prestasi belajar rendah ditunjukan dengan sedikit peserta didik yang memiliki gangguan jasmani atau yang memiliki kendala pada panca indera. Menurut (Dariyo, 2013:90) kesehatan fisik yang prima akan mendorong individu dalam melaksanakan kegiatan belajar dengan bagus agar bisa memperoleh keberhasilan belajar yang baik juga. Begitupun peserta didik yang sakit, ditambah dengan keadaan sakit yang parah dan diharuskan mendapatkan perawatan di rumah sakit, maka individu tidak bisa berkonsentrasi belajar dengan bagus. Tidak hanya sulit dalam mendapatkan prestasi belajar dengan baik tetapi bisa saja mengalami kegagalan dalam belajar. Sedangkan menurut Mustamin \& Sulasteri (2013:5) seseorang yang kondisinya segar, jasmaninya akan lebih baik dari seseorang yang berada pada kondisi lelah. Seseorang yang kekurangan gizi terungkap kemampuannya berada di bawah individu yang tidak kekurangan gizi. Seseorang yang kurang gizi mudah lelah cepat mengantuk, dan sulit menerima pelajaran.

Pada penjabaran tersebut bisa peneliti simpulkan bahwa faktor jasmani yang rendah bukan berarti tidak ada siswa yang mengalami gangguan jasmani saat meraih prestasinya. Ada beberapa siswa yang mengalami gangguan jasmani yang perlu mendapat perhatian dari kelas dan guru Bimbingan dan Konseling. Untuk itu perlu kejasama antara guru dan sekolah agar peserta didik yang 
mengalami gangguan jasmani dapat teratasi.

b. Faktor Internal yang Mempengaruhi Prestasi Belajar Peserta Didik Dilihat dari Faktor Psikologis Hasil penelitian menonjolkan faktor internal yang mempengaruhi prestasi belajar dilihat dari faktor psikologisdi SMK Negeri 3 Kota Padang berada pada kategori cukup tinggi (46,81\%). Artinya sebagian besar siswa mempunyai faktor psikologis yang sangat rendah. Menurut menurut (Winkel, 2001:35) Faktor psikologis, faktor ini berkaitan erat dengan intelegensi, tingkah laku dan motivasi yang muncul pada dalam diri anak itu sendiri. Keadaan psikologis dapat mempengaruhi peserta didik dalam meraih prestasi belajarnya. Menjaga keadaan pskologis selama proses belajar mengajar sangat penting untuk dipahami oleh guru kelas, guru BK dan pihak sekolah. Guru kelas perlu menjaga iklim psikologis peserta didik selama proses belajar supaya siswa mudah memahami pelajaran yang diterima. Selain itu bagi guru BK sangat penting artinya untuk memperhatikan keadaan psikogis peserta didik. Apabila terjadi gangguang atau maslah psikologis peserta didik guru $\mathrm{Bk}$ bias mengetahui dan membantu peserta didik melalui layanan yang ada pada BK. Sehingga peserta didik tidak larut dalam permasalahan psikologis yang dihadapinya. Sedangkan menurut Mustamin \& Sulasteri (2013:5) faktor psikologis yaitu faktor dari dalam yang yaitu poin penting saat menetapkan intensitas belajar seseorang. Meskipun faktor eksternal atau sekitar mendukung, tetapi faktor psikologis kurang mendorong maka faktor luar tidak berlaku. Karenanya potensi, intelegensi, minat dan kemampuan kognitif yaitu faktor psikologis yang penting mempengaruhi proses dan prestasi belajar siswa.

$$
\text { Pada penjabaran }
$$

tersebut bisa peneliti 


$$
\begin{aligned}
& \text { simpulkan bahwa faktor } \\
& \text { psikologis yang mempengaruhi } \\
& \text { prestasi belajar yang rendah } \\
& \text { ditunjukan dengan masih } \\
& \text { tingginya motivasi peserta } \\
& \text { didik dalam meraih } \\
& \text { prestasinya, ada peserta didik } \\
& \text { yang mau belajar dengan tekun } \\
& \text { untuk meraih prestasinya. } \\
& \text { Selain itu peserta didik } \\
& \text { memiliki keyakinan apabila } \\
& \text { mereka belajar dengan serius } \\
& \text { maka mereka mampu } \\
& \text { mendapat prestasi belajar yang } \\
& \text { ingin dicapai. Peserta dikik } \\
& \text { juga berusaha mengumpulkan } \\
& \text { atau melengkapi tugas yang } \\
& \text { diberikan pendidik. }
\end{aligned}
$$

2. Faktor Internal yang Mempengaruhi Prestasi Belajar Peserta Didik

Hasil Penelitian menjabarkan bahwa faktor eksternal yang mempengaruhi prestasi belajar siswa terdapat 13 orang siswa $(28,89 \%)$ yang memiliki fakto eksternal yang cukup tinggi, sebanyak 25 orang peserta didik $(55,56 \%)$ yang memiliki faktor eksternal yang rendah, sebanyak 7 orang peserta didik $(15,56 \%)$ yang memiliki faktor eksternal yang sangat rendah dan tidak terdapat siswa yang memiliki faktor eksternal ada pada klasifikasi yang sangat tinggi dan tinggi. Jadi, faktor eksternal yang mempengaruhi prestasi belajarsiswa di SMK Negeri 3 Kota Padang berada pada kategori rendah $(55,56 \%)$. Artinya sebagian besar peserta didik memiliki faktor eksternal yang rendah

Selanjutnya akan dibahas secara perindikator :

a. Faktor Internal yang Mempengaruhi Prestasi Belajar Peserta Didik Dilihat dari Faktor Sosial

Hasil penelitian faktor eksternal yang mempengaruhi prestasi belajar dilihat dari faktor sosialdi SMK Negeri 3 Kota Padang berada pada kategori rendah $(46,00 \%)$. Artinya sebagian besar peserta didik memiliki faktor sosial yang rendah.

Menurut (Dariyo, 2013:36) lingkungan sosial kelas (Class Climate

Environment) merupakan keadaan sosial individu dan 
psikologis yang muncul disaat proses pembelajaran yang dilakukan oleh pendidik dan siswa di kelas. Suasana kelas yang tenang, nyaman mendorong peserta didik besemanagat saat belajar dan memahami materi pembelajaran.

Peneliti simpulkan bahwa faktor sosial yang mempengaruhi prestasi belajar yang rendah ditunjukan masih tingginya dukungan social yang diberikan oleh orangtua kepada peserta didik. Selain dukungan social dari orangtua, dukuangan dari teman sebaya membantu pesertadidik dalam menggapai prestasi maksimalnya. Berada dilikungan yang mendukung membuat peserta didik bersemangat dalam belajar. Membantu peserta didik dalam menggapai prestasi maksimalnya. Berada di likungan yang mendukung membuat peserta didik bersemangat dalam belajar. b. Faktor Internal yang Mempengaruhi Prestasi Belajar Peserta Didik Dilihat dari Faktor Budaya

Hasil penelitian menunjukan faktor eksternal yang mempengaruhi prestasi belajar dilihat dari faktor budayadi SMK Negeri 3 Kota Padang berada pada kategori rendah (46,67\%). Artinya sebagian besar peserta didik memiliki faktor budaya yang cukup tinggi.

Menurut Syafi'i et al., (2018:36) anak dalam mencapai prestasi belajar yang baik. Anak haruslah dapat bersosialisasi dengan masyarakat sekitarnya, karena dari pengalaman yang didapat anak dimasyarat banyak didapat ilmu yang berguna bagi anak didik. Faktor budaya seperti peraturan adat, wawasan, teknologi, kesenian.

Pada penjabaran tersebut bisa peneliti simpulkan bahwa budaya yang mempengaruhi prestasi belajar yang rendah ditunjukan dengan kebiasaan disiplin yang 
diterapkan dalam keluarga jadi siswa lebih rajin dalam belajar. Selain itu metode mengajar guru yang bervariasi memacu semangat belajar siswa.

c. Faktor Internal yang Mempengaruhi Prestasi Belajar Peserta Didik Dilihat dari Faktor Lingkungan fisik

Hasil penelitian
menunjukan faktor dari luar
diri siswa dipengaruhi oleh
faktor lingkungan fisik di SMK
Negeri 3 Kota Padang berada
pada kategori cukup tinggi
$(48,89 \%)$. Artinya sebagian
besar peserta didik memiliki
faktor lingkungan fisik yang
cukup tinggi.

Menurut

(Dariyo, 2013:76). Lingkungan fisik sekolah (school physical environmental)

yaitu lingkungan yang berupa prasarana dan sarana yang ada di sekolah individu. Prasarana dan sarana yang bagus dilengkapi dengan ruang kelas dengan pencahayaan yang bagus, saringan angin yang bagus, adanya AC (penyejuk ruangan), adanya
LCD, papan tulis (whiteboard), spidol, perpustakaan lengkap, labor dan sarana belajar lainnya. Lengkap atau tidak sarana dan prasarana bisa memberi pengaruh untuk anak pada keberhasilan belajar. Sedangkan menurut Mustamin \& Sulasteri, (2013: 44) Faktorfaktor instrumental yaitu yang menggunakannya dengan dirancang berdasarkan pencapaian belajar yang diinginkan. Faktor-faktor ini diminta bisa berguna dalam sarana agar terwujudnya tujuan yang sudah direncanakan. Faktor-faktor tersebut meliputi : gedung, perlengkapan belajar, alat-alat labor, dan sebagainya. Pada penjabaran tersebut bisa peneliti simpulkan bahwa faktor lingkungan fisik yang cukup tinggi mempengaruhi prestasi belajar peserta didik. Factor lingkungan fisik berhubungan dengan fasilitias yang disediakan oleh sekolah, selain fasilitas sekolah fasilitas belajar yang ada di rumah turut 
mempengaruhi prestasi belajar peserta didik. Factor lingkungan fisik dapat dilihat dari bagaimana orangtua melengkapi fasilitas dan keperluan belajar peserta didik dirumah. Sekolah juga menyediakan fasilitas yang menunjang proses belajar mengajar disekolah.

\section{KESIMPULAN}

Berdasarkan hasil penelitian tentang faktor yanng mempengaruhi prestasi belajar siswa kelas X SMK 3 Negeri Kota Padang diantaranya:

1. Prestasi peserta didik yang di pengaruhi oleh faktor internal ada pada klasifikasi rendah.

2. Prestasi peserta didik yang dipengaruhi oleh faktor eksternal ada pada klasifikasi rendah.

\section{DAFTAR PUSTAKA}

Bhakti, C. P. 2015. Bimbingan dan Konseling Komprehensif: dari Paradigma Menuju Aksi. Jurnal Fokus Konseling, 1(2), 100.

Bungin, Burhan. 2005. Metode Penelitian Kualitatif. Jakarta: Prenada Media.
Dariyo, Agoes. 2013. Dasar-dasar Pedagogik Modern. Jakarta. Indeks Permata Puri Media

Hikmawati Fenti, M.Si. 2011. Bimbingan dan Konseling. Jakarta: Raja Grafindo

Iskandar. 2009. Metodologi Penelitian Pendidikan dan Sosial Kuantitatif dan Kualitatif. Jakarta: GP Press.

Mustamin, S. H. M., \& Sulasteri, S. (2013). Faktor-faktor yang Mempengaruhi Prestasi Belajar Mahasiswa Jurusan Pendidikan Matematika Fakultas Tarbiyah dan Keguruan UIN Alauddin Makassar.Jurnal Matematika DanPembelajaran, 1(1), 151175.alauddin.ac.id/index.php/M apan/article/view/1136

Putu, N., Nonik, S., Sulastri, M., \& Sedanayasa, G. 2014. Penerapan Layanan Bimbingan Belajar untuk Menungkatkan Prestasi Belajar Bagi Siswa yang Mengalami Kesulitan Belajar Siswa Kelas X4 SMA Negeri 1 Sukasada.. Undiksa Jurusan Bimbingan Konseling, 2(1),2

Rahim, A., Atan, R., \& Kamaluddin, A. (2011). Intellectual capital reporting in Malaysian technology industry.Asian Journal of Accounting andGovernance, 2, 51-59

Syafi'i, A., Marfiyanto, T., \& Rodiyah, S. K. (2018). Studi Tentang Prestasi Belajar Siswa Dalam Berbagai Aspek dan 
Faktor

yang

Mempengaruhi.Jurnal

Komunikasi Pendidikan, 2(2),

121. 